Ann. Biol. anim. Bioch. Biophys., 1979, 19 (3 B), 739-747.

\title{
Absorption kinetics of amino acids and reducing sugars during digestion of barley or wheat meals in the pig : Preliminary data
}

par A. RÉRAT, P. VAISSADE, P. VAUGELADE $\left({ }^{1}\right)$

Laboratoire de Physiologie de la Nutrition, I.N.R.A., 78350 Jouy-en-Josas, France.

Summary. The digestion of barley and wheat was studied in the pig using a methodology quantitatively describing the apparent absorption kinetics of amino acids and reducing sugars. This methodology is based on the simultaneous and continuous measurement of the postprandial increase of the level of these nutrients in the efferent blood of the digestive tract (porto-arterial differences) and the measurement of the portal vein blood flow. After an 18-hr fast, the experimental meals (18 for barley, 22 for wheat) were given to animals weighing 40 to $50 \mathrm{~kg}$ in amounts varying from 200 to $1600 \mathrm{~g}$; recordings were taken over a periprandial period of 10 to $12 \mathrm{hrs}$. The following main results were obtained: 1) wheat was digested more rapidly than barley. Eight hours after the meal, 35 to 43 p. 100 of the barley amino acids appeared in the blood as against 53 to 56 p. 100 of those from wheat. The differences were less for the sugars ( 36 to 43 p. 100 for barley vs 44 to 48 p. 100 for wheat). Small amounts of cereals were more rapidly digested than large amounts ; 2) for both cereals, the appearance of amino acids in the blood varied with the amino acid. As concerns essential amino acids, histidine, aromatic amino acids and methionine appeared more rapidly. On the other hand, arginine and cystine appeared more slowly, unless they were metabolized in the digestive wall. Among the non-essential amino acids, glutamine and glutamic acid appeared very slowly and alanine and glycocolle very quickly and intensely; non-alimentary products such as citrulline and ornithine were synthesized. Absorption balance after $8 \mathrm{hrs}$ of digestion, as shown by absorption percentages, ranged from 71p.100 (histidine) to 20 p. 100 (cystine) for barley and between 90 and 29 p. 100 (same amino acids) for wheat. Alanine in the case of both cereals and glycine in the case of wheat, were synthesized. The absorption coefficient of glutamic acid and glutamine was very low in both cases.

\section{Introduction.}

The apparent digestibility of nutrients is usually calculated using data supplied by the digestibility technique which consists of measuring the quantities of nutrients disappearing between the oral and aboral extremes of the digestive tract. This method, however, is insufficient from a quantitative aspect and in terms of absorption kinetics.

(1) With the technical assistance of P. Robin and D. Robin for the amino acid analysis, Centre de Recherches sur la Nutrition, C.N.R.S. 
From a quantitative point of view, the disappearance of a nutrient while passing through the digestive tract does not necessarily signify that the nutrient has been absorbed, and it does not in any case indicate in which form it has appeared in the organism. This nutrient may indeed be destroyed or modified in the digestive tract by the microflora; it may proceed from the body fluids and be excreted in the digestive tract.

With the digestibility method, it is impossible to accurately determine chronologically whether the various nutrients are absorbed at different rates. And yet, it seems that the simultaneous input of a mino acids on the sites of protein synthesis and the synchronism of the supply of sugars and amino acids to the tissues may greatly affect feed efficiency.

We thus decided to develop a technique for direct measurement of absorption, accounting for the amounts of nutrients that appeared in the organism, their nature and absorption kinetics. This method was used for studying the absorption of some nutrients (amino acids, sugars) after the consumption of two cereals (barley, wheat).

\section{Material and methods.}

1. - Principle and modalities of the method.

The method used (Rérat, 1971b, 1977) quantifies the enrichment in various nutrients (sugars, amino acids, etc.), of the intestinal efferent blood by simultaneously measuring porto-arterial concentration differences $(\mathrm{Cp}-\mathrm{Ca})$ and blood flow rate (D) in the portal vein. The amounts absorbed $(q)$ during the experimental period (dt) are given by the formula : $q=(C p-C a) D d t$.

This measurement only concerns apparent absorption, as some nutrients proceeding from the intestinal lumen or from the arterial blood may be metabolized or catabolized in the gastro-intestinal wall. The data obtained for an ingested nutrient correspond to excessive absorption relative to tissue metabolism when the porto-arterial difference is positive, or to excessive tissue metabolism relative to absorption when the porto-arterial difference is negative. On the other hand, the apparent synthesis of a non-ingested nutrient by the gastro-intestinal wall can be measured in this way.

The application of this method requires that the animals be fitted with an electromagnetic probe for measuring the blood flow rate in the portal vein (Rérat, 1971a), and with two catheters permanently placed in the portal vein (Arsac and Rérat, 1962) and in the left brachiocephalic artery through the carotid route. Painless blood samples can thus be taken from the porto-hepatic system and the arterial circulation of conscious animals and the blood flow rate in the portal vein simultaneously measured.

During the experiments, samples were taken over the whole periprandial period (from $30 \mathrm{~min}$ before the meal until 8 to $12 \mathrm{hrs}$ after), either discontinuously to obtain voluminous samples (chromatographic analysis of amino acids), or continuously by connecting the cannulae directly to an automatic analyser. Analyses were carried out according to previously described techniques (Rérat, 1977).

2. - Animals and diets.

This method has been used in 40 to $50 \mathrm{~kg}$ pigs for studying the absorption of amino acids (liquid-phase chromatography or analysis of $\alpha$-amino nitrogen), reducing 
sugars, glucose and lactic acid after ingestion of meals composed of cereals (barley or wheat) mixed with 3 p. 100 minerals. The meal was given in the morning after $18 \mathrm{hrs}$ of fasting ; the amounts allotted ranged from 200 to $1600 \mathrm{~g}$

Cereal composition is given in table 1 .

TABLE 1

Chemical composition of cereals ingested

\begin{tabular}{|c|c|c|}
\hline & Barley & Wheat \\
\hline 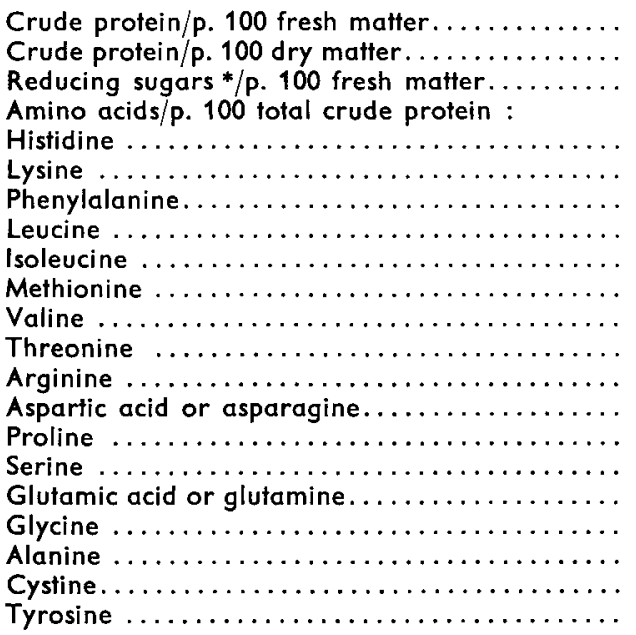 & $\begin{array}{l}9.82 \\
10.84 \\
63.7 \\
\\
2.10 \\
3.70 \\
4.90 \\
6.70 \\
3.50 \\
1.65 \\
5.00 \\
3.20 \\
5.10 \\
5.70 \\
10.4 \\
3.85 \\
22.15 \\
3.90 \\
3.90 \\
2.40 \\
3.15\end{array}$ & $\begin{array}{c}12.45 \\
14.10 \\
66.4 \\
\\
2.35 \\
2.85 \\
4.85 \\
6.40 \\
3.50 \\
1.70 \\
4.35 \\
2.75 \\
5.00 \\
4.90 \\
10.0 \\
4.25 \\
28.25 \\
3.75 \\
3.35 \\
2.50 \\
3.05\end{array}$ \\
\hline
\end{tabular}

* Starch + sugars soluble in alcohol + pentosans.

\section{Results.}

These preliminary data concern 22 meals for wheat and 18 meals for barley, 7 of which were respectively obtained by chromatography. Qualitative data will be reported in the definitive publication.

1. - Variation in amounts of amino acids and sugars appearing in the organism at different times after the meal.

The cumulated mean amounts of amino acids and reducing sugars appearing in the organism at different times after the meal are shown in table 2. Compared with the intake level, the amounts of nutrients absorbed were higher for wheat than for barley during the whole experimental period, i. e. after $8 \mathrm{hrs}, 11$ to 21 p. 100 reducing sugars according to the intake level, and 26 to 49 p. 100 amino acids. 
With the wheat meals, absorption was rapid and the amounts appearing in the organism during the first $2 \mathrm{hrs}$ of digestion seemed to depend only slightly on the amounts ingested ; this was contrary to the case of barley. Thus, the absorption coefficients calculated from the amounts ingested were substantially lower for the nutrients resulting from barley digestion than for those resulting from wheat digestion. Carbohydrate digestion seemed to be slower than that of proteins in the case of wheat but not of barley.

TABLE 2

Amounts (mean t.. standard error of mean) of amino acids and reducing sugars absorbed during the postprandial period after the intake of a cereal (wheat or barley).

I. - Amino acids

\begin{tabular}{|c|c|c|c|c|c|c|c|}
\hline & \multirow{2}{*}{$\begin{array}{l}\text { Total } \\
\text { fresh } \\
\text { matter } \\
(g)\end{array}$} & \multirow{2}{*}{$\begin{array}{c}\text { Intake } \\
\text { proteins } \\
\text { (g) }\end{array}$} & \multirow[b]{2}{*}{$N$} & \multicolumn{4}{|c|}{ Time after the meal (hrs) } \\
\hline & & & & 2 & 4 & 6 & 8 \\
\hline Barley & $\begin{array}{l}800 \\
1200 \\
1600\end{array}$ & $\begin{array}{r}78.6 \\
117.8 \\
157.1\end{array}$ & $\begin{array}{l}7 \\
2 \\
3\end{array}$ & $\begin{array}{c}8.6 \pm 0.9 \\
12.43 \\
14.9 \pm 0.6\end{array}$ & $\begin{array}{c}18.8 \pm 2.2 \\
26.8 \\
28.9 \pm 1.3\end{array}$ & $\begin{array}{c}28.8 \pm 3.6 \\
39.8 \\
42.1 \pm 2.7\end{array}$ & $\begin{array}{c}33.9 \pm 3.9 \\
48.2 \\
54.1 \pm 4.7\end{array}$ \\
\hline Wheat & $\begin{array}{r}800 \\
1200 \\
1600\end{array}$ & $\begin{array}{r}99.6 \\
149.4 \\
199.2\end{array}$ & $\begin{array}{l}7 \\
8 \\
3\end{array}$ & $\begin{array}{l}19.4 \pm 3.6 \\
20.1 \pm 1.9 \\
26.1 \pm 2.5\end{array}$ & $\begin{array}{l}32.3 \pm 4.7 \\
42.1 \pm 3.5 \\
55.8 \pm 2.8\end{array}$ & $\begin{array}{l}45.9 \pm 5.1 \\
61.0 \pm 4.7 \\
81.5 \pm 6.1\end{array}$ & $\begin{array}{r}55.7 \pm 6.8 \\
80.4 \pm 6.3 \\
105.7 \pm 6.4\end{array}$ \\
\hline
\end{tabular}

II. - Reducing sugars

Intake Intake of
of fresh reducing
matter sugars

(g) (g)

\begin{tabular}{lrrrcccc}
\hline Barley & 800 & 510 & 3 & $56.6 \pm 10.1$ & $130.3 \pm 22.2$ & $181.8 \pm 31.6$ & $220.2 \pm 33.5$ \\
& 1600 & 1019 & 2 & 95.7 & 213.6 & 305.1 & 370.1 \\
Wheat & 800 & 531 & 4 & $104.6 \pm 21.3$ & $194.2 \pm 30.2$ & $233.5 \pm 33.0$ & $255.8 \pm 31.4$ \\
& 1200 & 797 & 6 & $102.3 \pm 6.8$ & $200.9 \pm 13.8$ & $280.2 \pm 24.9$ & $336.0 \pm 32.8$ \\
& 1600 & 1062 & 2 & 130.0 & 286.0 & 396.0 & 467.1 \\
\hline
\end{tabular}

The relationships between the amounts of nutrients absorbed and the quantities ingested were studied in order to include all the feed intake levels used ; these relationships can be explained by first degree equations (table 3 ).

A comparison of the two cereals again shows that wheat proteins were digested more rapidly, the phenomenon being more evident with higher intake levels; the slopes of the regression lines established after $8 \mathrm{hrs}$ were significantly different for wheat and barley proteins. In addition, the slope of the regression line of wheat protein was significantly different from that of the wheat reducing sugars, indicating a 
differential digestion of these two nutrients. On the other hand, as concerned the reducing sugars of the two cereals or the reducing sugars and crude protein of barley, there was no difference between the slopes of the lines representing a variation in the amounts absorbed in relation to the amounts ingested. In spite of this, the digestion of wheat carbohydrates seemed to be faster than that of barley carbohydrates, the advantage being less marked than for proteins.

TABLE 3

Relationships between absorbed level $(y / g)$ and intake level $(X / g) 8 \mathrm{hrs}$ after the meal

\begin{tabular}{|c|c|c|c|c|c|c|}
\hline & $n$ & Regression : $Y=$ & $r$ & $\begin{array}{l}\bar{x} \\
(g)\end{array}$ & $\begin{array}{c}\bar{Y} \\
(g)\end{array}$ & $\begin{array}{c}\text { Significance } \\
\text { (1) }\end{array}$ \\
\hline \multicolumn{7}{|l|}{ Wheat } \\
\hline RS $\ldots \ldots \ldots$ & 16 & $0.366 x+56.939$ & 0.821 & 626.9 & 286.4 & $* *$ \\
\hline$\alpha$ AN........ & 16 & $0.459 x+14.244$ & 0.805 & 117.6 & 68.2 & $* *$ \\
\hline \multicolumn{7}{|l|}{ Barley } \\
\hline RS $\ldots \ldots \ldots$ & 12 & $0.309 x+47.001$ & 0.880 & 475.4 & 193.9 & $* *$ \\
\hline$\alpha$ AN......... & 12 & $0.302 x+9.230$ & 0.842 & 74.5 & 31.2 & $* *$ \\
\hline
\end{tabular}

(1) NS : non-significant ; ** significant at the threshold 0.01 :

RS : reducing substances,

$\alpha$ AN : $\alpha$ amino nitrogen.

2. - Composition of the amino acid mixture appearing in the organism and amino acid apparent absorption coefficient.

As the regression of the amounts of amino acids absorbed on the amounts ingested could not be calculated due to an insufficient number of chromatographical analyses (7 experimental meals for each cereal, representing 210 blood samples), the results were expressed in the form of the patterns of amino acids absorbed (relative to either the sum of essential amino acids or the sum of non-essential amino acids). These patterns were then compared with the amino acid profile of the ingested proteins (tables 4,5 ). The relative absorption rates of the various essential cmino acids were thus determined in respect to the mixture of essential amino acids, and the non-essential ones relative to the mixture of non-essential amino acids.

The behavior of the two cereals was very similar. Thus, table 4 shows that the transport of all the essential amino acids through the digestive tract seemed to be a little faster than that of the non-essential ones (108 for wheat, 109 for barley), or that a small fraction of the non-essential amino acids disappeared during absorption. As compared with the whole amount of essential amino acids, some appeared comparatively faster than others ; this was particularly true for histidine, less marked for aromatic amino acids and even less evident for methionine, isoleucine and, in the case of wheat, for threonine and valine. Leucine seemed to behave like the overall mixture of 
TABLE 4

Composition of the essential amino acid mixture appearing in the organism during an $8 \mathrm{hr}$ period after a barley meal $(\mathrm{N}=7)$ or a wheat meal $(\mathrm{N}=7)$

\begin{tabular}{|c|c|c|c|c|c|c|}
\hline & \multicolumn{3}{|c|}{ Barley } & \multicolumn{3}{|c|}{ Wheat } \\
\hline & \multicolumn{2}{|c|}{$\begin{array}{l}\text { p. } 100 \text { of total } \\
\text { essential amino acids }\end{array}$} & \multirow{2}{*}{$\begin{array}{l}\Delta \\
\overline{\mathbf{m}}\end{array}$} & \multicolumn{2}{|c|}{$\begin{array}{l}\text { p. } 100 \text { of total } \\
\text { essential amino acids }\end{array}$} & \multirow{2}{*}{$\begin{array}{l}\Delta \\
\overline{\mathbf{m}}\end{array}$} \\
\hline & $\bar{m}$ & $\mathrm{Sm}$ & & $\overline{\mathrm{m}}$ & $\mathrm{Sm}$ & \\
\hline 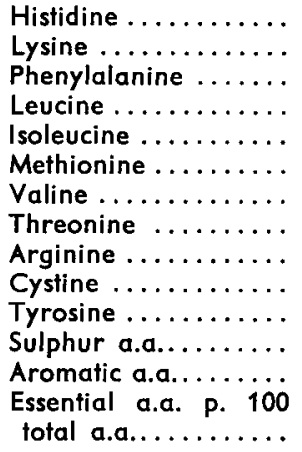 & $\begin{array}{r}8.25 \\
8.13 \\
13.04 \\
16.19 \\
9.07 \\
4.80 \\
11.79 \\
7.54 \\
8.0 \\
2.66 \\
10.06 \\
8.10 \\
23.67 \\
45.80\end{array}$ & $\begin{array}{l}1.18 \\
0.82 \\
0.31 \\
0.55 \\
0.50 \\
0.47 \\
1.15 \\
0.48 \\
0.97 \\
0.87 \\
0.32 \\
1.30 \\
0.17 \\
\\
1.23\end{array}$ & $\begin{array}{r}160.7 \\
90.3 \\
109.3 \\
100.8 \\
108.4 \\
117.5 \\
96.9 \\
98.0 \\
65.2 \\
54.4 \\
139.1 \\
83.0 \\
120.9 \\
109.9\end{array}$ & $\begin{array}{c}8.27 \\
6.54 \\
14.34 \\
16.37 \\
10.19 \\
5.4 \\
12.3 \\
8.03 \\
6.32 \\
2.76 \\
9.39 \\
8.13 \\
23.73 \\
\\
42.54\end{array}$ & $\begin{array}{l}0.56 \\
0.33 \\
0.36 \\
0.53 \\
0.28 \\
0.66 \\
0.55 \\
0.39 \\
1.13 \\
0.79 \\
0.35 \\
1.42 \\
0.55 \\
\\
1.42\end{array}$ & $\begin{array}{r}137.9 \\
89.2 \\
118.1 \\
100.7 \\
113.8 \\
125.7 \\
111.2 \\
113.6 \\
49.7 \\
43.3 \\
129.2 \\
76.4 \\
122.2 \\
108.3\end{array}$ \\
\hline
\end{tabular}

$\Delta$ : Deviation (p. 100) from the pattern of essential amino acids in the ingested proteins.

TABLE 5

Composition of the non-essential amino acid mixture appearing in the organism during an $8 \mathrm{hr}$ period after a barley meal $(\mathrm{n}=7)$ or a wheat meal $(\mathrm{N}=7)$

\begin{tabular}{|c|c|c|c|c|c|c|}
\hline & \multicolumn{3}{|c|}{ Barley } & \multicolumn{3}{|c|}{ Wheat } \\
\hline & \multicolumn{2}{|c|}{$\begin{array}{l}\text { p. } 100 \text { of total non- } \\
\text { essential amino acids }\end{array}$} & \multirow{2}{*}{$\begin{array}{l}\Delta \\
\overline{\mathrm{m}}\end{array}$} & \multicolumn{2}{|c|}{$\begin{array}{l}\text { p. } 100 \text { of total non- } \\
\text { essential amino acids }\end{array}$} & \multirow{2}{*}{$\begin{array}{c}\Delta \\
\overline{\mathrm{m}}\end{array}$} \\
\hline & $\overline{\mathrm{m}}$ & $\mathrm{Sm}$ & & $\overline{\mathrm{m}}$ & $\mathrm{Sm}$ & \\
\hline 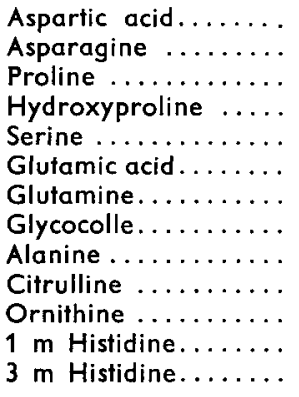 & $\begin{array}{r}2.60 \\
7.50 \\
14.1 \\
- \\
8.44 \\
2.48 \\
4.72 \\
11.77 \\
31.41 \\
8.33 \\
3.85 \\
1.25 \\
1.42\end{array}$ & 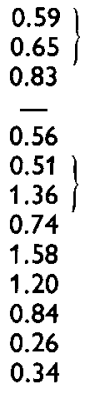 & $\begin{array}{c}88.6 \\
\overline{68.4} \\
\overline{111.1} \\
16.2 \\
\overline{147.9} \\
397.8 \\
- \\
-\end{array}$ & $\begin{array}{r}2.04 \\
5.23 \\
16.09 \\
1.29 \\
10.12 \\
3.57 \\
11.04 \\
11.65 \\
26.50 \\
6.61 \\
3.28 \\
0.89 \\
1.61\end{array}$ & 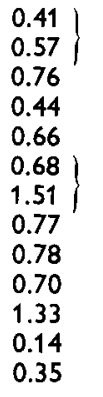 & $\begin{array}{r}80.8 \\
88.5 \\
128.8 \\
28.2 \\
168.1 \\
472.2\end{array}$ \\
\hline
\end{tabular}

$\Delta$ : Deviation (p. 100) from the pattern of non-essential amino acids in the ingested proteins. 
essential amino acids. The transport time of other amino acids was always longer ; it was very marked for arginine and cystine and less evident for lysine.

The mixture of non-essential amino acids was radically modified for both cereals (table 5). Only a very small fraction of the sum of glutamic acid + glutamine was recovered; the sum of aspartic acid + asparagine and proline was not completely recuperated. Serine was absorbed a litfle more rapidly than the mixture of non-essential amino acids, and glycine even faster. Alanine represented the extreme case, its concentration in the mixture absorbed being 4-fold higher than in the mixture ingested. In addition, some non-essential amino acids appeared in large amounts during absorption (citrulline, ornithine) or in small amounts (hydroxyproline, methylhistidine).

Owing to the difference between the pattern of amino acid mixtures appearing in the organism and that of the mixtures ingested, as well as to the total amino acid absorption percentage obtained by statistical computation (table 3), we could estimate the apparent absorption coefficient after $8 \mathrm{hrs}$ for each of the amino acids (table 6).

TABLE 6

Calculated absorption coefficient of various amino acids $8 \mathrm{hrs}$ after a barley or wheat meal (for $100 \mathrm{~g}$ crude protein intake)

\begin{tabular}{|c|c|c|c|c|c|c|}
\hline & \multicolumn{3}{|c|}{ Barley } & \multicolumn{3}{|c|}{ Wheat } \\
\hline & $\begin{array}{l}\text { Total } \\
\text { intake } \\
\text { (g) }\end{array}$ & $\begin{array}{l}\text { Amount } \\
\text { absorbed } \\
\text { (g) }\end{array}$ & & $\begin{array}{l}\text { Total } \\
\text { intake } \\
(\alpha)\end{array}$ & $\begin{array}{l}\text { Amount } \\
\text { absorbed }\end{array}$ & \\
\hline Total crude protein............. & 100 & 39.4 & 39.4 & 100 & 60.1 & 60.1 \\
\hline 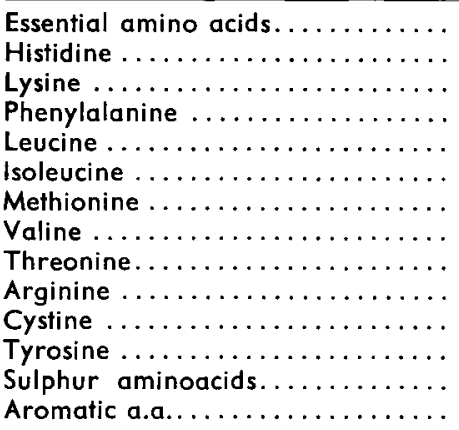 & $\begin{array}{l}41.5 \\
2.10 \\
3.70 \\
4.90 \\
6.70 \\
3.50 \\
1.65 \\
5.00 \\
3.20 \\
5.10 \\
2.40 \\
3.15 \\
4.0 \\
8.10\end{array}$ & $\begin{array}{r}18.05 \\
1.50 \\
1.46 \\
2.35 \\
2.92 \\
1.64 \\
0.77 \\
2.13 \\
1.35 \\
1.44 \\
0.49 \\
1.91 \\
1.46 \\
4.28\end{array}$ & $\begin{array}{l}43.5 \\
71.4 \\
39.5 \\
48.0 \\
43.6 \\
47.0 \\
46.7 \\
42.6 \\
42.2 \\
28.2 \\
20.4 \\
60.6 \\
36.5 \\
52.8\end{array}$ & $\begin{array}{c}39.30 \\
2.35 \\
2.85 \\
4.85 \\
6.40 \\
3.50 \\
1.70 \\
4.35 \\
2.75 \\
5.0 \\
2.5 \\
3.05 \\
4.20 \\
7.90\end{array}$ & $\begin{array}{r}25.54 \\
2.12 \\
1.66 \\
3.65 \\
4.19 \\
2.61 \\
1.38 \\
3.14 \\
2.0 \\
1.61 \\
0.72 \\
2.40 \\
20.07 \\
6.05\end{array}$ & $\begin{array}{l}65.0 \\
90.2 \\
58.2 \\
75.3 \\
65.5 \\
74.6 \\
81.2 \\
72.3 \\
72.7 \\
32.2 \\
28.8 \\
78.7 \\
49.3 \\
76.6\end{array}$ \\
\hline 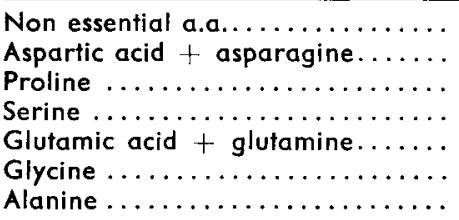 & $\begin{array}{c}58.5 \\
5.70 \\
10.4 \\
3.83 \\
22.15 \\
3.90 \\
3.90\end{array}$ & $\begin{array}{r}21.35 \\
2.15 \\
3.01 \\
1.79 \\
1.54 \\
2.52 \\
6.70\end{array}$ & $\begin{array}{r}36.5 \\
37.7 \\
28.9 \\
46.5 \\
7.0 \\
64.6 \\
171.8\end{array}$ & $\begin{array}{c}60.70 \\
4.90 \\
10.0 \\
4.25 \\
28.25 \\
3.75 \\
3.35\end{array}$ & $\begin{array}{r}35.46 \\
2.51 \\
5.56 \\
3.49 \\
5.06 \\
4.04 \\
9.16\end{array}$ & $\begin{array}{r}56.9 \\
51.2 \\
55.6 \\
82.1 \\
17.9 \\
107.7 \\
273.4\end{array}$ \\
\hline $\begin{array}{l}\text { Citrulline } \ldots \ldots \ldots \ldots \ldots \ldots \ldots \ldots \ldots \\
\text { Ornithine } \ldots \ldots \ldots \ldots \ldots \ldots \ldots \\
\text { Arginine }+ \text { Citrulline }+ \text { Ornithine }\end{array}$ & & $\begin{array}{l}1.78 \\
0.82 \\
4.04\end{array}$ & & & $\begin{array}{l}2.28 \\
1.13 \\
5.02\end{array}$ & \\
\hline
\end{tabular}


Eight hours after intake of $100 \mathrm{~g}$ of barley proteins (about $1 \mathrm{~kg}$ of barley), $43 \mathrm{p} .100$ of the essential amino acids appeared in the organism of the pig. However, this percentage varied between 20 and 28 p. 100 (cystine and arginine, respectively) and 71 p. 100 (histidine). Furthermore, very small percentages of glutamic acid and glutamine appeared in the organism contrary to what has been observed for alanine, which was highly synthesized. Accordingly, there seemed to be considerable transamination in the gastro-intestinal wall, leading to a degradation of glutamine and glutamic acid and the appearance of large amounts of alanine.

Even more marked analogous phenomena were observed with wheat. The absorpfion rate of all amino acids was faster than for barley, but the patterns were similar to those found with barley. Besides the synthesis of alanine and glycocolle, that of citrulline and ornithine was higher than in the case of barley.

Commission CNERNA Digestion-Absorption/Association des Physiologistes, Paris 5-6 octobre 1978.

Résumé. La digestion de deux céréales (orge, blé) a été étudiée chez le Porc à l'aide d'une méthodologie permettant de décrire quantitativement la cinétique de l'absorption apparente des acides aminés et des sucres réducteurs. Cette méthodologie est basée sur la mesure parallèle et continue de l'augmentation post-prandiale de concentration de ces nutriments dans le sang efférent du tube digestif (différences porto-artérielles) et celle du débit de sang dans la veine porte. Les repas expérimentaux (18 pour l'orge, 22 pour le blé) ont été fournis aux animaux (40-50 kg de poids) en quantités variant entre 200 et $1600 \mathrm{~g}$, après une période de jeône de $18 \mathrm{~h}$, et les enregistrements ont porté sur une période périprandiale de 10 à $12 \mathrm{~h}$.

Les principaux résultats obtenus sont les suivants :

- La digestion du blé est plus rapide que celle de l'orge. Huit heures après le repas, 35 à 43 p. 100 des acides aminés en provenance de l'orge ont apparu dans le sang porte, contre 53 à 56 p. 100 dans le cas du blé. Les différences sont moins importantes dans le cas des sucres ( 36 à 43 p. 100 pour l'orge, contre 44 à 48 p. 100 pour le blé). La digestion est plus rapidement achevée dans le cas des faibles quantités que dans celui des fortes quantités de céréales ingérées.

- L'apparition des acides aminés dans le sang est plus ou moins rapide selon l'acide aminé considéré, les phénomènes constatés étant parallèles dans le cas des deux céréales. Au plan des acides aminés essentiels, on constate une apparition plus rapide de l'histidine, des acides aminés aromatiques, et de la méthionine; à l'inverse, l'apparition d'arginine et de cystine paraît plus lente, à moins qu'il ne se produise une métabolisation de ces acides aminés dans la paroi digestive. Au plan des acides aminés non essentiels, on constate l'apparition très réduite de glułamine et d'acide glutamique et une apparition très rapide et intense d'alanine et de glycocolle ; il faut également noter la synthèse de produits non alimentaires (citrulline, ornithine). Le bilan d'absorption après 8 heures de digestion se traduit par des pourcentages d'absorption s'étalant entre 71 p. 100 (histidine) et 20 p. 100 (cystine) pour l'orge, et 90 et 29 p. 100 (mêmes aminoacides) pour le blé ; on enregistre une synthèse massive d'alanine pour les deux céréales et une synthèse de glycocolle pour le blé ; le coefficient d'absorption de l'acide glutamique et de la glutamine est très faible dans les deux cas. 


\section{References}

ARSAC M., RÉRAT A., 1962. Technique de fistulation de la veine porte chez le porc. Ann. Biol. anim. Bioch. Biophys., 2, 335-344.

RÉRAT A., 1971a. Mesure du débit de sang dans la veine porte à l'aide d'un débitmètre électromagnétique chez le porc. Ann. Biol. anim. Bioch. Biophys., 11, 175-180.

RÉRAT A., 1971b. Mise au point d'une méthode quantitative d'étude de l'absorption chez le porc. Ann. Biol. anim. Bioch. Biophys., 11, 277.

RÉRAT A., 1977. Mise au point d'une méthode quantitative d'éfude de l'absorption digestive chez le porc. Applications à quelques problèmes nutritionnels concrets. Bull. Acad. vét. France, 50, 93-107. 